\title{
Study on the realization of pause groups and breath groups*
}

\author{
Doyoung Yoo · Jiyoung Shin** \\ Department of Korean Language and Literature, Korea University, Seoul, Korea
}

\begin{abstract}
The purpose of this study is to observe the realization of pause and breath groups from adult speakers and to examine how gender, generation, and tasks can affect this realization. For this purpose, we analyzed forty-eight male or female speakers. Their generation was divided into two groups: young, old. Task and gender affected both the realization of pause and breath groups. The length of the pause groups was longer in the read speech than in the spontaneous speech and female speech. On the other hand, the length of the breath group was longer in the spontaneous speech and the male speech. In the spontaneous speech, which requires planning, the speaker produced shorter length of pause group. The short sentence length of the reading material influenced the reason for which the length of the breath group was shorter in the reading speech. Gender difference resulted from difference in pause patterns between genders. In the case of the breath groups, the male speaker produced longer duration of pause than the female speaker did, which may be due to difference in lung capacity between genders. On the other hand, generation did not affect either the pause groups or the breath groups. The generation factor only influenced the number of syllables and the eojeols, which can be interpreted as the result of the difference in speech rate between generations.
\end{abstract}

Keywords: pause, pause group, breath, breath group, length of utterance, prosody, temporal pattern

\section{1. 서론}

인간의 음성언어는 음성이 산출되는 조음 구간과, 음성이 산 출되지 않는 묵음 구간으로 구성되어 있다. 긴 길이의 발화를 지속할 때, 화자는 중간 중간 묵음, 즉 휴지를 삽입함으로써 음 성을 적당한 양씩 끊어서 산출하게 된다. 발화를 산출하기 위해 서는 지속적인 기류 조달이 필요한데, 이를 위해 숨을 들이쉬는
동안에는 음성을 산출할 수 없다. 따라서 발화 내에는 필연적으 로 휴지 구간이 생기게 된다. 이 외에도 발화 내의 휴지 구간은 발화 계획, 발화 전략, 발화 수정 등의 목적을 위해서도 나타난 다. 따라서 인간의 음성 언어는 조음 구간과 휴지 구간이 번갈 아 나타나는 연쇄적인 패턴으로 구성됨을 알 수 있다. 그렇다면 음성 언어에서 조음 구간과 휴지 구간은 구체적으로 어떠한 실현 양상을 나타내는가? 이 연구는 이러한 질문에서부터 시작한다.

\footnotetext{
* This work was supported by the Ministry of Education of the Republic of Korea and the National Research Foundation of Korea (NRF2019S1A5A2A03044146).

**shinjy@korea.ac.kr, Corresponding author

Received 31 January 2020; Revised 19 March 2020; Accepted 19 March 2020

(C) Copyright 2020 Korean Society of Speech Sciences. This is an Open-Access article distributed under the terms of the Creative Commons Attribution NonCommercial License (http://creativecommons.org/licenses/by-nc/4.0) which permits unrestricted non-commercial use, distribution, and reproduction in any medium, provided the original work is properly cited.
} 
휴지 구간의 실현에 대해서는 많은 연구들에서 이미 논의가 이루어진 바가 있다. 앞선 연구들에 따르면 휴지의 실현은 성별, 세대, 언어적 요인, 운율적 요인, 인지적 요인 등에 따라 다양한 양상을 보인다(Cappella, 1985; Ferreira, 1991; Henderson et al., 1966; Kendall, 2009; Lee et al., 2017 등). 일반적으로 남성이 여 성보다, 청년층이 장년층보다 길고 잦은 휴지의 실현을 보이며 (Kendall, 2009; Lee et al., 2017), 언어적이거나 인지적으로 더 복 잡하고 부담이 있는 문장을 발화할 때 휴지가 길고 잦아진다 (Henderson et al., 1966). 또 휴지 전후의 발화 길이가 길수록 휴 지의 길이 또한 길어진다(Ferreira, 1991). 한편 조음 구간의 실현 은 지금까지 거의 연구의 대상이 되지 못했다. 그러나 휴지 구 간에 대한 연구만으로는 조음 구간과 휴지 구간이 번갈아 나타 나는 발화의 전체적인 시간적 구성을 이해하는 데 한계가 있다. 따라서 발화의 전반적인 시간적 구성을 이해하기 위해서는 조 음 구간에 대한 연구 역시 뒷받침 되어야 할 필요가 있다. 이 연 구는 발화를 구성하는 조음 구간의 실현을 구체적으로 관찰할 것이다.

조음 구간의 실현은 여러 가지 요인에 의해 영향을 받을 수 있다. 우선, 음성 언어의 실현은 산출 과정에서 음성 기관의 동 작들을 요구하기 때문에 필연적으로 화자들의 생리적인 차이 가 반영될 수밖에 없다. 또한 화자의 발화는 사회적 정체성을 드러내며(Foulkes \& Docherty, 2006), 청자 역시 화자의 사회적 지위에 기반하여 그들의 발화를 해석한다(Strand et al., 1999). 인간의 발화는 이처럼 사회 문화적인 요인에 영향을 받는다. 따 라서 성별, 세대와 같은 변수들이 조음 구간의 실현에 영향을 줄 것으로 예상할 수 있다.

이밖에도 조음 구간의 실현 양상은 발화의 난이도에 영향을 받는다. 화자가 발화를 일정한 양씩 끊어 말하는 데에는 생리적 인 이유 이외에도 인지적이거나 언어적인 이유가 관여하기 때 문이다(Henderson et al., 1965; Rochet-Capellan \& Fuchs, 2013). 앞선 연구들에 따르면 인지적으로 부담이 있는 상황에서 발화 의 길이가 더 짧아지거나(Henderson et al., 1965), 통사적인 경계 나 간투사 전후에 들숨을 쉬는 경우가 많으므로, 통사 구조가 호 흡 단위의 길이에 영향을 준다고 보고 하였다(Rochet-Capellan \& Fuchs, 2013). 따라서 복잡한 문장 구조의 유무, 인지적 부담량 의 차이 등에 따른 발화 난이도 역시 조음 구간의 실현에 영향 을 미치는 주요한 변수라고 할 수 있다.

이에 본 연구는 생리적이거나 사회 언어적인 차이와 더불어 발화 난이도에 따른 차이를 관찰할 수 있도록 성별, 세대, 과제 와 같은 변수에 초점을 맞추고자 한다. 이들은 조음 구간의 실 현에 영향을 주는 것으로 보고되거나, 영향을 줄 것으로 예측되 는 변수들이기 때문이다. 조음 구간의 실현이 이러한 변수들에 따라 어떠한 양상으로 나타나는지 살피고, 그러한 실현을 보이 는 원인을 인지 언어적, 사회 언어적, 생리적 변수와 연관 지어 해석해 보고자 한다.

이 연구의 관찰 대상은 조음 구간으로, 휴지와 휴지 사이에 관찰되는 말소리들이다. 휴지는 크게 호흡을 동반한 휴지와 호 흡을 동반하지 않는 휴지로 구분할 수 있는데, 이에 따라 조음
구간도 두 가지 유형으로 나눌 수 있다. 휴지 단위와 호흡 단위 이다. 휴지 단위란 휴지 구간과 휴지 구간 사이에 실현된, 중간 에 휴지 구간이 개입되지 않고 실현된 조음 구간, 즉 한 번의 휴 지를 통해 실현된 발화의 시간 단위를 의미한다. 또, 호흡 단위 란 들숨 동반 휴지와 들숨 동반 휴지 사이에 실현된, 중간에 들 숨 동반 휴지가 개입되지 않고 실현된 말소리의 구간, 즉 한 번 의 들숨을 통해 지속된 발화의 시간 단위를 의미한다. 본 연구 에서는 휴지 단위와 호흡 단위를 구분하여 관찰할 것인데, 휴지 단위 분석을 통하여 전반적인 조음 구간의 길이를 살피고, 호흡 단위 분석을 통하여 호흡량과 같은 생리적인 차이가 조음 구간 실현에 영향을 미치는지 확인하기 위해서이다.

휴지 단위나 호흡 단위의 실현이 언어 내·외적 상황에 따라 서로 다른 실현 양상을 보임을 보고한 연구들이 있다. 그중에서 도 휴지 단위에 대한 연구는 휴지 연구와 병행되어 언급된 것이 대다수이다. 이러한 연구로는 Henderson et al.(1965), Watson \& Gibson(2004), Kendall(2013)을 들 수 있다. Henderson et al.(1965) 은 과제에 따른 휴지 실현과 휴지 간 발화 길이의 실현을 살폈 다. 이 연구에서 저자는 낭독 발화보다 자유 발화에서 긴 휴지 와 짧은 발화 길이가 관찰되며, 이러한 패턴이 발화 계획과 관 련되어 있다고 설명했다. Watson \& Gibson(2004), Kendall(2013) 에서는 휴지의 길이와 휴지 전후의 발화 길이가 휴지 실현에 영 향을 준다고 하였는데, 휴지 길이가 길수록 후행하는 발화의 길 이 또한 길어진다고 설명하였다.

한국어의 휴지 단위를 살핀 국내 연구는 거의 찾아보기 드물 다. 발화 길이에 대해 언급한 연구들이 몇몇 존재하는데, 이러 한 연구들은 대체로 병리학적 관점에서 장애군 화자와 비장애 군 화자의 비교 연구로 수행되었다(Chon \& Lee, 2019; Jung \& Yoon, 2013; Kim, 2017; Lee \& Hwang, 2001). 그러나 이 연구들 은 하나의 완결된 발화나 문장 단위를 연구 대상으로 하였기 때 문에, 본 연구에서 관심이 있는 휴지 단위와는 연구 대상이 다 르다고 할 수 있다.

이 외에 휴지 단위의 실현을 관찰한 연구는 거의 찾기 어렵 다. 휴지 단위에 대해 살핀 해외 몇몇 해외 연구들은 휴지와의 관련성을 위주로 설명되었기 때문에, 휴지 단위 그 자체로 면밀 한 분석이나 논의가 이루어진 것이라고 보기 어렵다. 또 휴지 단위의 실현은 성별이나 세대와 같은 생리적, 사회 언어학적 변 수들에 따라서 다양한 실현 양상을 보일 수 있다. 그럼에도 휴 지 단위에 대한 대상으로 성별이나 세대와 같은 변수에 따른 실 현의 차이를 본격적으로 살핀 국내외 연구들은 거의 찾아보기 힘들다.

한편 호흡 단위에 대한 연구는 좀 더 다양한 방향으로 진행되 었다. 먼저 과제에 따른 호흡 단위 실현의 차이를 살핀 연구로 는 Winkworth et al.(1994, 1995)과 Wang et al.(2010), Lee et al.(2012)을 들 수 있다. Winkworth et al.(1994, 1995)은 각각 성인 6명의 낭독 발화와 자유 발화에서 나타나는 호흡의 패턴을 관 찰한 것으로, 자유 발화와 낭독 발화에서 관찰된 호흡 단위의 길이가 과제의 차이를 보이지 않는다고 결론지었다. 한편 Wang et al.(2010)은 20 64세의 북미 영어 화자 남녀 16명의 발화 분석 
을 통해 호흡 단위의 과제 간 차이를 관찰하였는데, 연구 결과 읽기 과제보다 자유 발화의 호흡 단위 길이가 더 길다고 보고하 였다. 한국어를 대상으로 과제별 차이를 살핀 Lee et al.(2012)은 성인 여성 15 명을 대상으로 낭독 발화와 자유 발화에서 관찰되 는 호흡 능력 차이를 연구하였는데, 호흡 단위의 길이가 문단 읽기에서 더 길게 나타남을 밝혔다. 위의 연구들에서 확인할 수 있는 사실은, 과제에 따른 호흡 패턴의 실현 결과가 연구에 따 라 다소 상이하다는 점이다. 따라서 과제에 따른 호흡 패턴 양 상을 재고할 수 있는 연구가 필요하다.

성별이나 세대에 따른 호흡 패턴의 차이를 살핀 연구들도 존 재한다. 세대에 따른 호흡 패턴의 차이를 살핀 연구로는 Sperry $\& \operatorname{Klich}(1992)$ 를 들 수 있다. 20 30대 여성과 60 70대 여성의 낭 독 발화를 비교한 이 연구에서는 흡기의 수, 흡기 시 기류의 속 도, 날숨 시 공기의 양, 낭독 시 기류 속도가 세대 간 차이를 보 이지 않았으며, 들숨 시 공기의 양만이 세대 차이를 보였음을 보였다. Shin(2018)에서도 20대 남녀 6명의 자유 발화에서 관찰 된 호흡 단위를 분석하면서, 성별 차이에 대해 간단히 언급하였 다. 이 연구에서 저자는 한 호흡을 통해 산출되는 한국어의 발 화의 길이가 약 3.3 초, 음절 수는 약 19.8 음절 정도로 나타남을 언급하면서, 성별 차이는 발견되지 않았다고 보고하였다. 그러 나 이 연구는 성별에 따른 실현 차이를 관찰하는 것이 주된 목 적이 아니었으므로, 성별 차이에 대해 자세하게 고찰하는 연구 가 새롭게 이루어져야 할 필요가 있다.

지금까지 살펴본 바와 같이 휴지 단위나 호흡 단위의 실현이 발화 계획 여부나 문장의 복잡성과 같은 인지적 측면, 혹은 성 별이나 세대와 같은 사회 언어학적 차이를 반영하고 있음을 알 수 있다. 그럼에도 휴지 단위나 호흡 단위의 실현 양상에 영향 을 줄 수 있는 요소를 다각도로 살펴본 연구는 거의 이루어지지 않았으며, 수행된 연구도 대체로 결과가 일관되지 않거나 분석 규모가 크지 않다는 아쉬움이 남는다. 따라서 휴지 단위나 호흡 단위의 실현에 영향을 줄 수 있는 요인들을 인지 언어적, 생리 적, 사회 언어적 차이와 연결 지어 해석할 수 있는 연구가 필요 하다고 할 수 있다. 더불어, 한국어를 대상으로 발화의 전체적 인 시간 구성을 살핀 연구는 거의 찾기 어렵다는 점에서 한국어 발화의 휴지 단위, 호흡 단위에 대한 전반적인 실현 양상을 확 인할 수 있는 연구가 필요하다고 할 수 있다.

이에 본 연구는 과제, 세대, 성별에 따른 휴지 단위와 호흡 단 위의 실현 양상을 살피고, 변수에 따른 실현 양상의 차이가 초 래된 이유를 인지적, 생리적, 사회 언어적 차이와 연관 지어 해 석해 보고자 한다. 이를 위해 청·장년층 성인 남녀 화자의 낭독 발화와 자유 발화의 과제의 휴지 단위와 호흡 단위의 실현을 살 펴볼 것이다.

\section{2. 연구 방법}

\section{1. 분석 자료}

본 연구에 사용된 자료는 대규모 음성 코퍼스인 한국인 표준 음성 데이터베이스(Shin \& Kim, 2017) 중 일부다. 이 코퍼스는
발화자의 사회적 요소가 균형을 가질 수 있도록, 전국 9개 권역 의 성인 남녀를 5 개 연령층으로 구분하여 총 3,000 명 이상의 발 화를 수집한 대규모 음성 코퍼스이다. 본 연구는 해당 코퍼스에 서 수도권 청년층 화자(20 35세) 남녀 12명씩 24명, 장년층 화 자(50 65세) 남녀 12명씩 24명, 총 48명의 화자를 임의 선정하 여 연구 대상으로 삼았다.

분석 대상이 된 발화 자료는 피험자들이 수행한 다섯 가지 발 화 과제(모음 발성, 문단 낭독, 문장 낭독, 괄호 메워 말하기, 자 유 발화) 중 문단 낭독 자료와 자유 발화 자료였다. 문단 낭독 과 제는 11 개 문장으로 구성된 한 개 문단을 낭독하는 것이었고, 자유 발화 과제는 3 분 정도의 자발적인 말하기를 수행하는 것 이었다. 낭독 발화 자료는 모든 발화자의 자료를 연구 대상으로 삼았으나, 자유 발화 자료의 경우에는 선정된 48 명의 피험자 중 비유창한 발화 및 부적절한 과제 수행이 관찰된 2 명의 발화 자 료를 분석 대상에서 제외하였다. 분석 대상이 된 피험자를 과제 별로 세대와 성별을 구분하여 제시하면 표 1 과 같다.

표 1. 낭독/자유 발화의 피험자 수(단위, 명)

Table 1. The number of subjects for read/spontaneous speech

\begin{tabular}{c|c|c|c}
\hline & 남(낭독/자유) & 여(낭독/자유) & 계 \\
\hline 청년층 & $12 / 12$ & $12 / 11$ & $24 / 23$ \\
\hline 장년층 & $12 / 11$ & $12 / 12$ & $23 / 24$ \\
\hline 계 & $24 / 23$ & $24 / 23$ & $48 / 46$ \\
\hline
\end{tabular}

분석 대상이 된 자료의 총 규모는 낭독 자료 총 2,447 어절, 자 유 발화 자료 총 15,650 어절로 총 18,907 어절이었으며, 휴지 단 위의 개수는 총 4,717 개, 호흡 단위는 총 2,582 개 토큰이었다.

\section{2. 분석 방법}

본 연구에서는 발화의 시간 구성을 두 가지로 휴지 단위와 호 흡 단위로 구분하여 분석하였다. 휴지 단위는 휴지와 휴지 사이 에 실현된 발화의 길이를 의미하며, 발화 계획이나 발화 수행상 의 난이도, 혹은 유창성과 같은 지표들을 반영한다. 호흡 단위 는 들숨 동반 휴지 간 발화 길이로, 한 호흡으로 지속된 발화의 길이를 의미한다. 본래 음운론에서 사용되는 호흡 단위(breath group)의 의미는 음높이 조정이 이루어지는 운율 단위를 의미하 는 개념으로(Libermann, 1967), 실제 생리적인 호흡이 이루어지 는 단위와 정확히 일치하지 않는다. 본 연구에서는 이와 같은 개념적인 정의에서 벗어나, 호흡 단위를 '한 호흡으로 지속된 발화의 단위'라는 뜻으로 조작적 정의하였다. 따라서 본 연구에 서 호흡 단위는 화자가 한 숨으로 지속한 발화를 의미한다.

휴지 단위와 호흡 단위를 살펴보기 위하여 발화에 나타나는 휴지를 두 가지 유형으로 나누어 주석하였다. 들숨을 동반한 휴 지와, 들숨을 동반하지 않은 휴지였다. 본 연구에서의 휴지는 0.1 초 이상의 물리적인 묵음으로 정의되었으며(Clopper \& Smiljanic, 2015; Lee et al., 2017; Shin, 2013; Wennerstrom et al., 2003), 휴지 기간 동안의 들숨 동반 여부는 스펙트로그램을 참고하여 연구 자가 듣고 판단하였다. 본 연구의 연구 대상이 된 녹음 자료가 


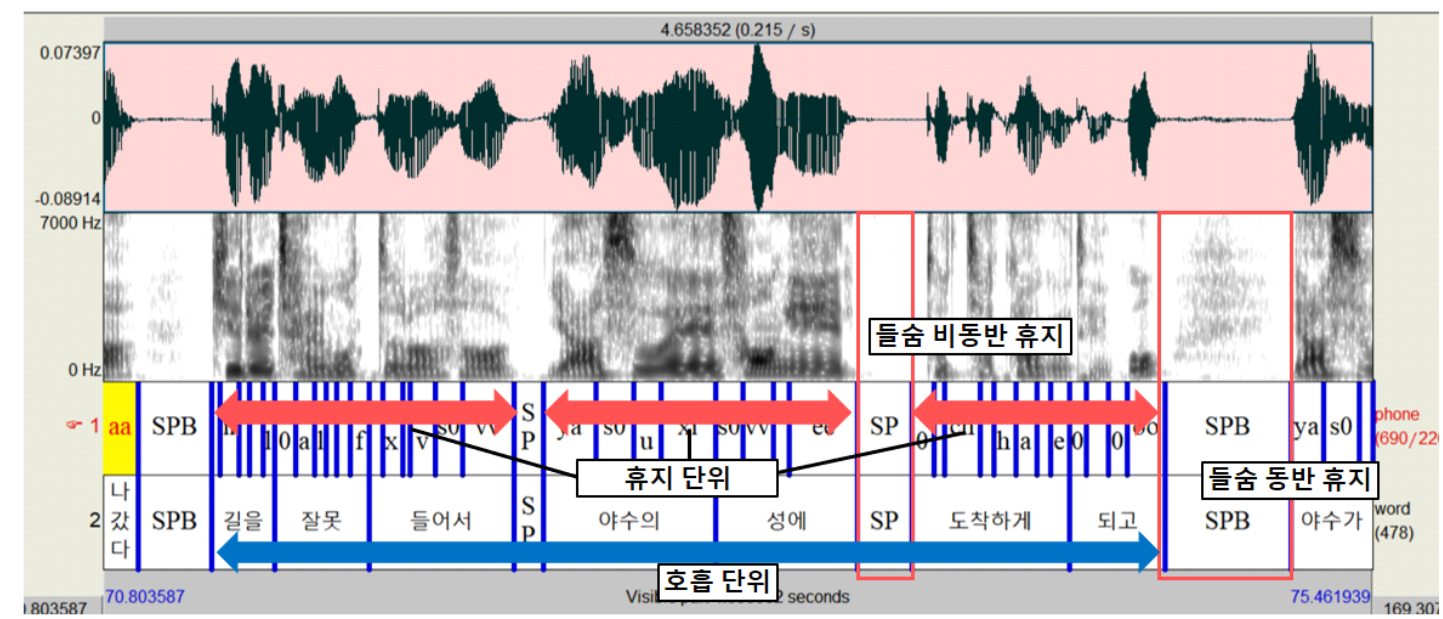

그림 1. Praat을 이용한 휴지 주석 예시

Figure 1. Example of annotation using Praat

대부분 녹음실 혹은 소음이 적은 환경에서 수집되었기 때문에 들숨이 동반된 휴지의 경우 거의 대부분 들숨으로 인한 마찰 소 음이 스펙트로그램상에서 관찰되었다. 마찰 소음이 명확히 관 찰되지 않는 경우는 휴지 단위 분석에서 제외하였다. 발화 중간 에 웃음이 섞인 부분이나 지나치게 비유창한 부분은 분석 대상 에서 제외하였으며, 2 초 이상의 긴 휴지가 실현된 경우도 비유 창한 발화의 일부로 보고 분석 대상에서 제외하였다. 음성 분석 에는 Praat 프로그램이 사용되었다. 그림 1은 위와 같은 분석 기 준에 따라 분석 대상 자료를 주석한 예를 보인 것이다. 이렇게 주석된 자료를 바탕으로 휴지 단위와 호흡 단위의 지속 시간, 음절 수, 어절 수를 측정하였다.

본 실험의 데이터는 화자별로 데이터 포인트의 수가 다른 자 료이다. 이러한 데이터의 경우, 일반적인 분산 분석을 수행하게 되면, 발화량이 많아 많은 데이터를 가지고 있는 화자들의 실현 결과가 전체 결과를 왜곡할 가능성이 있다. 본 연구에서는 이를 방지하기 위해 화자를 임의 효과로 하는 혼합 효과 모형(mixed effect model)을 수행하였다. 독립 변수는 과제(낭독/자유), 세대 (청년/장년), 성별(남/여), 종속 변수는 휴지 단위의 길이, 휴지 단위 내 발화 음절 수, 휴지 단위 내 어절 수, 호흡 단위의 길이, 호흡 단위 내 음절 수, 호흡 단위 내 어절 수였다. 통계 분석에는 $\mathrm{R}$ 프로그램이 사용되었다.

\section{3. 연구 결과}

\section{1. 휴지 단위의 실현 양상}

이 절에서는 발화 과제, 성별, 세대에 따른 휴지 단위 내 발화 실현 양상을 살펴볼 것이다. 휴지 단위 내 발화 실현 양상은 발 화 길이, 음절 수, 어절 수로 나누어 살펴보았다. 각 종속 변수들 이 각각 과제, 성별, 세대에 따라 어떠한 실현의 차이를 보이는 지 살펴보기 위해 과제, 성별, 세대를 독립 변수로, 화자를 임의 변수로 하는 혼합 효과 회귀 분석을 수행하였다.

먼저 휴지 단위의 길이에 미치는 요인을 살펴보기 위하여 발
화 과제, 성별, 세대에 따른 휴지 단위의 길이를 살펴보았다. 표 2 는 범주에 따른 휴지 단위의 평균 길이와 통계 검정에 따른 결 과를 정리한 것이다.

표 2. 휴지 단위의 평균 길이 $(\mathrm{ms})$ 와 다중 회귀 분석 결과 Table 2. Mean duration (ms) of pause group and statistical results from mixed effect regression model

\begin{tabular}{|c|c|c|c|c|}
\hline 분류 & 소분류 & $\begin{array}{l}\text { 휴지 단위의 평균 } \\
\text { 길이 ( } \pm \text { 표준 편차) }\end{array}$ & $\beta$ & $t$-value \\
\hline \multirow{2}{*}{ 과제 } & 낭독 발화 & $2,055( \pm 796)$ & \multirow{2}{*}{236.02} & \multirow{2}{*}{$5.15^{* * *}$} \\
\hline & 자유 발화 & $1,610( \pm 1,093)$ & & \\
\hline \multirow{2}{*}{ 성별 } & 남성 & $1,500( \pm 926)$ & \multirow{2}{*}{-200.18} & \multirow{2}{*}{$-4.37^{* * *}$} \\
\hline & 여성 & $1,885( \pm 1,178)$ & & \\
\hline \multirow{2}{*}{ 세 대 } & 청년 & $1,766( \pm 359)$ & \multirow{2}{*}{63.44} & \multirow{2}{*}{1.38} \\
\hline & 장년 & $1,597( \pm 444)$ & & \\
\hline
\end{tabular}

$\beta$, estimated value.

위 표에서 제시된 바와 같이 휴지 단위의 길이는 과제와 성별 에서 차이를 보였다. 과제의 경우, 낭독 발화 $(2,055 \mathrm{~ms})$ 가 자유 발화 $(1,610 \mathrm{~ms})$ 보다 길었다. 성별에 있어서는, 여성 화자의 휴지 단위의 길이가 평균 $1,885 \mathrm{~ms}$ 로, 평균 $1,500 \mathrm{~ms}$ 인 남성 화자보다 더 길었다. 세대의 경우 청년이 장년보다 휴지 단위의 길이가 길게 나타나는 경향을 보였으나, 그 차이는 통계적으로 유의미 하지 않았다. 단일 범주에 따른 주효과 이외에 휴지 단위의 길 이에 영향을 주는 변수 간 상호작용 효과는 관찰되지 않았다.

동일한 방식으로 휴지 단위 내 발화 음절 수가 과제, 성별, 세 대에 따라 어떤 실현 양상을 보이는지 살펴보았다. 표 3 은 각 변 수들에 따른 휴지 단위 내 평균 발화 음절 수와 통계 검정에 따 른 결과를 제시한 것이다. 
표 3. 휴지 단위 내 평균 음절 수와 다중 회귀 분석 결과

Table 3. Mean number of syllables per pause groups and statistical results from mixed effect regression model

\begin{tabular}{c|c|c|c|c}
\hline \multirow{2}{*}{ 분류 } & 소분류 & $\begin{array}{c}\text { 휴지 단위 내 평균 발화 } \\
\text { 음절 수 }( \pm \text { 표준 편차 })\end{array}$ & $\beta$ & $t$-value \\
\hline \multirow{2}{*}{ 과제 } & 낭독 발화 & $12.5( \pm 5.16)$ & \multirow{2}{*}{1.83} & \multirow{2}{*}{$6.53^{* * *}$} \\
\cline { 1 - 3 } & 자유 발화 & $9.2( \pm 7.08)$ & \multirow{2}{*}{-0.83} & \multirow{2}{*}{$-2.97^{* *}$} \\
\hline \multirow{2}{*}{ 성별 } & 남성 & $9.0( \pm 6.44)$ & \multirow{2}{*}{1.16} & \multirow{2}{*}{$4.12^{* * *}$} \\
\cline { 2 - 3 } & 여성 & $10.5( \pm 7.08)$ & & \\
\hline \multirow{2}{*}{ 세대 } & 청년 & $10.6( \pm 6.44)$ & & \\
\cline { 2 - 3 } & 장년 & $8.9( \pm 7.38)$ & &
\end{tabular}

${ }^{* * *}<<0.01,{ }^{* * *} p<0.001$.

$\beta$, estimated value.

음절 수는 휴지 단위의 길이와 다르게 세 가지 변수 모두에서 통계적으로 유의미한 차이를 보이는 것을 확인할 수 있다. 낭독 발화(12.5음절)가 자유 발화(9.2음절)보다, 여성 화자(10.5음절) 가 남성 화자보다(9.0음절), 청년층 화자(10.6음절)가 장년층 화자 (8.9음절)보다 더 많은 음절을 한 휴지 단위 내에서 산출하였다.

다음으로 휴지 단위 내에 실현된 발화 어절 수에 대하여 살펴 보았다. 표 4는 과제, 성별, 세대에 따른 휴지 단위 내 평균 발화 어절 수와 혼합 효과 회귀 분석 결과를 정리한 것이다.

표 4. 휴지 단위 내 평균 어절 수와 다중 회귀 분석 결과

Table 4. Mean number of eojeol per pause groupss and statistical results from mixed effect regression model

\begin{tabular}{|c|c|c|c|c|}
\hline 분류 & 소분류 & $\begin{array}{c}\text { 휴지 단위 내 평균 발화 } \\
\text { 어절 수( } \pm \text { 표준 편차) }\end{array}$ & $\beta$ & $t$-value \\
\hline \multirow{2}{*}{ 과제 } & 낭독 발화 & $4.19( \pm 1.72)$ & \multirow{2}{*}{0.10} & \multirow{2}{*}{1.04} \\
\hline & 자유 발화 & $4.06( \pm 2.73)$ & & \\
\hline \multirow{2}{*}{ 성별 } & 남성 & $3.79( \pm 2.49)$ & \multirow{2}{*}{-0.34} & \multirow{2}{*}{$-3.45^{* * *}$} \\
\hline & 여성 & $4.42( \pm 2.7)$ & & \\
\hline \multirow{2}{*}{ 세대 } & 청년 & $4.37( \pm 2.79)$ & \multirow{2}{*}{0.33} & \multirow{2}{*}{$3.34^{* *}$} \\
\hline & 장년 & $3.82( \pm 2.4)$ & & \\
\hline
\end{tabular}

$\beta$, estimated value.

어절 수는 성별과 세대에서 유의미한 차이를 보였다. 음절 수 와 마찬가지로, 여성이 남성보다, 청년이 장년보다 휴지 단위 내에서 더 많은 어절 수를 실현하는 것으로 확인되었다. 한편 낭독 발화와 자유 발화 사이의 유의미한 차이는 관찰되지 않았 다. 이러한 결과는 휴지 단위의 길이와 휴지 단위 내 음절 수가 자유 발화보다 낭독 발화에서 더 길고 많았던 것과는 달랐다. 휴지 단위 내 평균 발화 음절 수가 낭독 발화와 자유 발화 각각 12.5 음절, 9.2음절이었던 것을 생각해 보면, 낭독 발화는 한 어 절에 약 2.98음절(12.5음절/4.19음절)을, 자유 발화는 약 2.3음절 (9.2음절/4.06어절)을 발화한 셈이다. 이를 통해 자유 발화가 낭 독 발화보다 한 어절을 구성하는 음절 수가 더 적다는 것을 알 수 있다.

이상의 결과를 정리하면 다음과 같다. 과제의 차이는 휴지 단 위의 길이와 발화 음절 수에 영향을 주었다. 낭독 발화는 자유 발화보다 휴지 단위의 길이가 짧고, 한 단위 내에서 발화되는 음절 수도 적었다. 그러나 휴지 단위 내 어절 수는 과제 간 유의
미한 차이를 보이지 않았다. 성별 차이는 휴지 단위의 길이, 음 절 수, 어절 수 모두에서 유의미한 것으로 나타났다. 남성 화자 는 여성 화자보다 휴지 사이에 더 짧은 발화를 산출하였고, 실 현된 음절 수와 어절 수도 유의미하게 적었다. 세대 변수는 휴 지 단위 내 발화 음절 수와 어절 수에서만 유의미한 차이를 관 찰할 수 있었다. 청년층과 장년층은 휴지 사이에 발화 길이에 있어서는 유의미한 차이를 보이지 않았으나, 청년층이 장년층 에 비해 휴지와 휴지 사이에 유의미하게 더 많은 음절과 어절을 산출하였다.

3.2. 호흡 단위의 실현 양상

이 절에서는 한 호흡으로 얼마나 많은 양의 발화를 할 수 있 는지 살펴볼 것이다. 휴지 단위와 마찬가지로 호흡 단위 역시 지속 시간, 음절 수, 어절 수로 나누어 살펴보았다. 각 종속 변수 들이 각각 과제, 성별, 세대에 따른 실현 양상에 따라 어떠한 실 현의 차이를 보이는지 살펴보기 위해 과제, 성별, 세대를 독립 변수로, 화자를 임의 변수로 하는 혼합 효과 회귀 분석을 수행 하였다.

먼저 호흡 단위의 길이의 실현에 영향을 미치는 변수들을 확 인하기 위하여 과제, 성별, 세대에 따른 호흡 단위의 평균 길이 를 살펴보았다. 표 5는 호흡 각 범주에 따른 호흡 단위 길이의 평균값과 통계 분석 결과를 정리한 것이다.

표 5. 호흡 단위의 평균 길이 $(\mathrm{ms})$ 와 다중 회귀 분석 결과 Table 5. Mean duration (ms) of breath group and statistical results from mixed effect regression model

\begin{tabular}{|c|c|c|c|c|}
\hline 분류 & 소분류 & $\begin{array}{l}\text { 호흡 단위의 평균 } \\
\text { 길이 (土표준 편차) }\end{array}$ & $\beta$ & $t$-value \\
\hline \multirow{2}{*}{ 과제 } & 낭독 발화 & $3,012( \pm 1,488)$ & \multirow{2}{*}{-379.81} & \multirow{2}{*}{$-2.56^{*}$} \\
\hline & 자유 발화 & $3,392( \pm 2,651)$ & & \\
\hline \multirow{2}{*}{ 성별 } & 남성 & $3,688( \pm 3,132)$ & \multirow{2}{*}{514.17} & \multirow{2}{*}{$3.46^{* *}$} \\
\hline & 여성 & $3,034( \pm 1,765)$ & & \\
\hline \multirow{2}{*}{ 세대 } & 청년 & $3,517( \pm 2,426)$ & \multirow{2}{*}{96.25} & \multirow{2}{*}{0.65} \\
\hline & 장년 & $3,143( \pm 2,515)$ & & \\
\hline
\end{tabular}

${ }^{*} p<0.5,{ }^{* *} p<0.01$.

$\beta$, estimated value.

위 표에서 확인할 수 있듯이, 과제와 성별은 호흡 단위 길이 에 영향을 주는 변수였다. 이는 휴지 단위의 관찰에서와 유사한 결과였으나, 실현되는 양상에는 차이가 있었다. 휴지 단위의 길 이는 자유 발화보다 낭독 발화에서 더 길게 나타났으나, 호흡 단위 길이는 그 반대였다. 호흡 단위는 낭독 발화 $(3,012 \mathrm{~ms})$ 보다 자유 발화 $(3,392 \mathrm{~ms})$ 에서 더 길게 나타나, 화자가 낭독 발화에서 보다 자유 발화에서 한 호흡으로 더 길게 말한다는 것을 확인할 수 있었다. 성별 변수 역시 휴지 단위의 길이와 반대의 양상으 로 영향을 주었다. 남성은 한 호흡으로 발화할 수 있는 길이가 여성보다 유의미하게 더 길었다. 세대의 경우, 청년층이 장년층 보다 호흡 단위의 평균 길이가 길었으나 통계적으로 유의한 차 이를 보이지는 않았다.

다음으로는 한 호흡 단위 내 실현된 음절 수가 과제, 성별, 세 
대에 따라 어떤 실현을 보이는지 살폈다. 표 6은 각 변수에 따른 호흡 단위 내 평균 음절 수와 통계 분석 결과를 정리하여 보인 것이다.

표 6. 호흡 단위 내 평균 음절 수와 다중 회귀 분석 결과

Table 6. Mean number of syllables per breath group pauses and statistical results from mixed effect regression model

\begin{tabular}{|c|c|c|c|c|}
\hline 분류 & 소분류 & $\begin{array}{c}\text { 호흡 단위 내 평균 음절 } \\
\text { 수 ( } \pm \text { 표준 편차) }\end{array}$ & $\beta$ & $t$-value \\
\hline \multirow{2}{*}{ 과제 } & 낭독 발화 & $17.2( \pm 8.10)$ & \multirow{2}{*}{-0.19} & \multirow[b]{2}{*}{-0.34} \\
\hline & 자유 발화 & $17.0( \pm 11.7)$ & & \\
\hline \multirow{2}{*}{ 성별 } & 남성 & $18.9( \pm 13.3)$ & \multirow{2}{*}{2.35} & \multirow{2}{*}{$4.21^{* * *}$} \\
\hline & 여성 & $15.6( \pm 8.81)$ & & \\
\hline \multirow{2}{*}{ 세 대 } & 청년 & $18.7( \pm 12.1)$ & \multirow{2}{*}{1.79} & \multirow{2}{*}{$3.20^{* *}$} \\
\hline & 장년 & $15.6( \pm 9.94)$ & & \\
\hline \multicolumn{3}{|c|}{ 상호작용: 세대:성별 } & 1.34 & $2.40^{*}$ \\
\hline
\end{tabular}

${ }^{*} p<0.5,{ }^{* *} p<0.01,{ }^{* * *} p<0.001$.

$\beta$, estimated value.

위 표에서 확인할 수 있듯, 호흡 단위 내 음절 수는 성별과 세 대에서만 유의미한 차이를 보였다. 남성은 여성보다 더 많은 음 절 수를 한 호흡 단위 안에 발화하는 것으로 확인되었다. 호흡 단위 길이에서는 세대 차이가 관찰되지 않았지만, 음절 수에서 는 세대 차이가 관찰되었다. 청년층은 장년층보다 한 호흡으로 더 많은 음절을 산출하였다.

한편 음절 수는 과제 간 유의미한 차이를 보이지 않았다. 낭 독 발화의 호흡 단위 길이가 자유 발화보다 유의미하게 길었음 에도, 한 단위 안에 담고 있는 음절 수에서는 유의미한 차이가 없었다.

단일 변수에 따른 주효과 이외에 호흡 단위 내 음절 수 실현 에 영향을 주는 성별과 세대 간 상호작용 역시 관찰되었다. 그 림 2는 호흡 단위 내 음절 수에 대한 세대와 성별의 상호 작용을 보여주는 그림이다. $\mathrm{x}$ 축은 성별, $\mathrm{y}$ 축은 호흡 단위 내 음절 수이 며, 직선은 청년층, 점선은 장년층 화자의 결과이다.

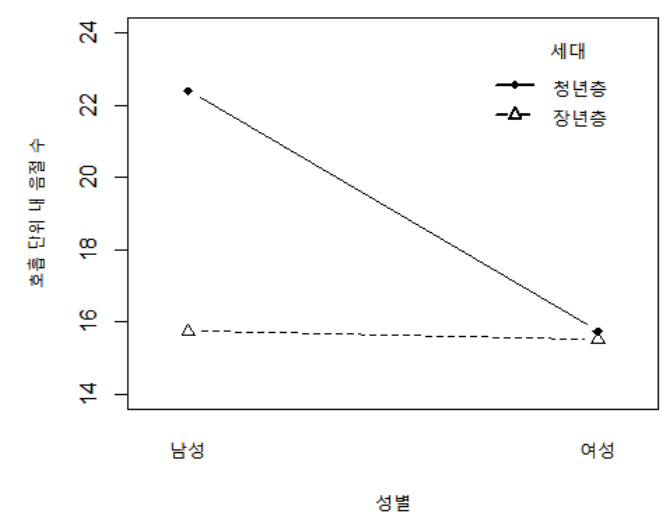

그림 2. 호흡 단위 내 음절 수의 성별, 세대 간 상호 작용(x축, 성별; $y$ 축, 호흡 단위 내 음절 수; 실선, 청년층 화자; 점선, 장년층 화자)

Figure 2. Interaction plot of gender and generation about number of syllables per breath group(X axis, generation; $Y$ axis, number of syllables per breath group; full line, younger speaker; dotted line, older speaker)
위 그림을 통해 청년층 남성과 나머지 세 집단이 호흡 단위 내 음절 수 실현에서 확연한 차이를 보이는 것을 알 수 있다. 청 년층 남성은 한 호흡으로 평균 22.4음절을 산출하는 반면, 청년 층 여성과 장년층 남녀 화자는 평균 약 15 음절을 산출한다. 청 년층 남성이 다른 세 집단과 구분되는 실현 양상을 보임에 따라, 성별 차이는 특히 청년층에서, 세대 차이는 남성층 화자에게서 두드러지게 나타나는 상호작용이 있음을 알 수 있다.

다음으로는 호흡 단위 내 어절 수를 살펴보았다. 표 7은 과제, 성별, 세대에 따른 호흡 단위 내 평균 어절 수와 통계 분석 결과 를 보인 것이다. 분석 결과 호흡 단위 내 평균 어절 수에 영향을 주는 변수는 과제, 성별, 세대 모두인 것을 확인할 수 있었다.

표 7. 호흡 단위 내 평균 어절 수와 다중 회귀 분석 결과

Table 7. Mean number of eojeol per breath group pauses and statistical results from mixed effect regression model

\begin{tabular}{|c|c|c|c|c|}
\hline 분류 & 소분류 & $\begin{array}{c}\text { 호흡 단위 내 평균 } \\
\text { 어절 수 ( } \pm \text { 표준 편차) }\end{array}$ & $\beta$ & $t$-value \\
\hline \multirow{2}{*}{ 과제 } & 낭독 발화 & $5.82( \pm 2.35)$ & \multirow{2}{*}{-1.05} & \multirow{2}{*}{$-5.15^{* * *}$} \\
\hline & 자유 발화 & $7.50( \pm 4.54)$ & & \\
\hline \multirow{2}{*}{ 성별 } & 남성 & $7.99( \pm 5.14)$ & \multirow{2}{*}{0.88} & \multirow{2}{*}{$4.28^{* * *}$} \\
\hline & 여성 & $6.56( \pm 3.31)$ & & \\
\hline \multirow{2}{*}{ 세대 } & 청년 & $7.73( \pm 4.58)$ & \multirow{2}{*}{0.51} & \multirow{2}{*}{$2.45^{*}$} \\
\hline & 장년 & $6.70( \pm 3.90)$ & & \\
\hline \multicolumn{3}{|c|}{ 상호작용: 세대:성별 } & 0.45 & $2.18^{*}$ \\
\hline
\end{tabular}

${ }^{*} p<0.5,{ }^{* * *} p<0.001$.

$\beta$, estimated value.

자유 발화는 한 호흡 단위에 포함된 어절 수가 7.5 개로, 낭독 발화인 5.82개보다 많았다. 남성은 7.99개, 여성은 6.56개로 남 성이 한 호흡으로 더 많은 수의 어절을 산출하였다. 청년층이 장년층보다 한 호흡 단위 안에 더 많은 어절을 산출하는 것으로 나타났다.

호흡 단위 내 평균 어절 수 역시 음절 수와 마찬가지로 세대 와 성별에 따른 상호작용이 관찰되었다. 그림 3 은 호흡 단위 내 어절 수 실현에 대한 세대와 성별의 상호 작용을 보여주는 그림 이다. $\mathrm{x}$ 축은 성별, $\mathrm{y}$ 축은 호흡 단위 내 어절 수이며, 직선은 청년 층, 점선은 장년층 화자의 결과이다. 


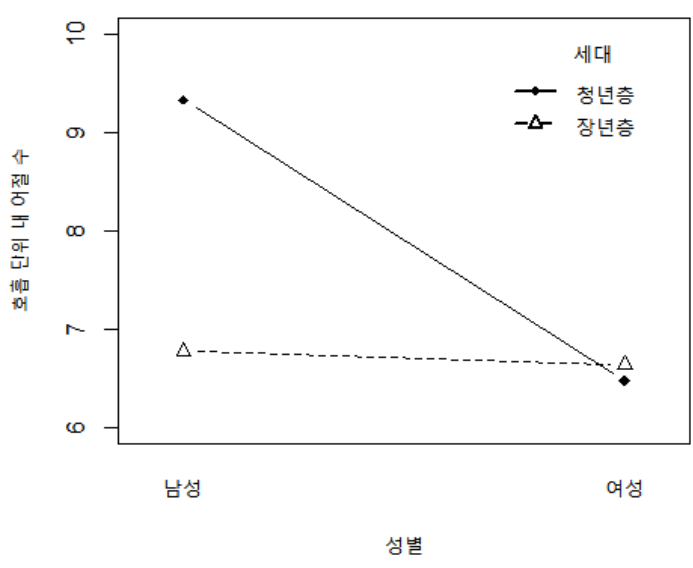

그림 3. 호흡 단위 내 어절 수의 성별, 세대 간 상호 작용(x축, 성별; $y$ 축, 호흡 단위 내 어절 수; 실선, 청년층 화자; 점선, 장년층 화자)

Figure 3. Interaction plot of gender and generation about number of eojeols per breath group(X axis, generation; $\mathrm{Y}$ axis, number of eojeols per breath group; full line, younger speaker; dotted line, older speaker)

호흡 단위 내 어절 수 역시, 청년층 남성과 나머지 세 집단의 차이가 두드러지는 양상을 보였다. 청년층 남성은 한 호흡 단위 내에 평균 9.33어절을 산출하였고 청년층 여성, 장년층 남녀 화 자는 각각 $6.58,6.77,6.64$ 어절을 한 호흡으로 산출하였다. 호흡 단위 내 음절 수의 실현 양상과 마찬가지로, 청년층 남성이 다 른 세 집단과 구분되는 실현 양상을 보임에 따라, 세대 차이는 남성층 화자에게서 두드러지게 나타나는 것을 확인할 수 있다.

이상의 결과를 정리하면 다음과 같다. 과제는 호흡 단위의 길 이와 평균 호흡 단위 내 어절 수 실현에 영향을 주었다. 자유 발 화의 호흡 단위가 낭독 발화보다 길었고, 한 호흡 단위 내의 어 절 수도 많았다. 그러나 호흡 단위 내 어절 수는 과제 간 차이를 보이지 않았다. 성별 차이는 호흡 단위의 길이, 호흡 단위 내 평 균 음절 수, 호흡 단위 내 평균 어절 수 모두에 영향을 주었다. 남성 화자는 여성 화자보다 한 호흡으로 더 많은 양의 발화를 지속할 수 있었다. 세대 변수는 호흡 단위 내 발화 음절 수와 어 절 수에만 영향을 주었다. 청·장년층은 호흡 단위 길이에서는 유의한 차이를 보이지 않았으나, 청년층은 한 호흡으로 더 많은 음절과 어절을 산출하였다.

\section{4. 논의}

\section{1. 과제별 차이}

발화 과제는 휴지 단위와 호흡 단위 실현에 모두 영향을 주었 다. 먼저, 휴지 단위의 길이는 낭독 발화에서 $2,055 \mathrm{~ms}$ 로 나타나, 자유 발화의 $1,610 \mathrm{~ms}$ 보다 길었다. 휴지 단위의 길이가 더 짧게 나타난다는 것은, 발화 내에 휴지가 자주 실현된다는 것을 의미 한다. 실제로 과제에 따른 휴지 실현을 살핀 Yoo \& Shin(2019) 에서 자유 발화에서 더 빈번하고 긴 휴지가 관찰된다고 보고한 바가 있다. 자유 발화에서의 더 빈번한 휴지의 출현은 더 짧은 휴지 단위의 실현을 초래한다.

이렇게 과제 간에 관찰되는 휴지 단위 길이의 차이는 두 과제
사이에 인지적 부담의 차이에 따른 결과라고 할 수 있다. 이는 긴 휴지와 짧은 발화가 발화 계획과 관련된다고 언급한 Henderson et al.(1965)의 연구와도 일치하는 결과이다. 화자의 즉각적이고 적 극적인 발화 계획이 요구되는 자유 발화에서는 길고 빈번한 휴 지가 출연하며, 이는 화자로 하여금 더 자주 발화를 끊어 말하 게 만든다. 따라서 긴 휴지 단위의 길이는 낭독 발화, 짧은 휴지 단위의 길이는 자유 발화의 특징이라고 할 수 있다.

반면 호흡 단위 길이는 휴지 단위의 길이와는 다른 실현을 보 였다. 호흡 단위의 길이는 자유 발화가 $3,392 \mathrm{~ms}$, 낭독 발화가 $3,012 \mathrm{~ms}$ 로 자유 발화에서 더 길게 나타났다. 더 짧은 휴지 단위 길이를 보이는 것이 낭독 발화의 특징이라고 했을 때, 호흡 단 위의 길이는 이에 반하는 결과를 보인 것이다.

이러한 결과가 나타난 데에는 낭독 시 제공한 대본의 문장 길 이에서 그 원인을 찾아볼 수 있다. Winkworth et al.(1994)은 문장 이나 절이 끝나기 전까지 화자가 새로운 쉼을 거의 들이쉬지 않 는다고 보고하였고, Rochet-Capellan \& Fuchs(2013)와 Bailly \& Gouvernayre(2012) 역시 들숨 동반 휴지가 통사적 경계나 구두 점 뒤에서 잘 나타난다고 하였다. 이러한 점을 고려해 보면, 낭 독 발화의 호흡 단위는 대본에 제시된 문장 구성에 영향을 받았 을 가능성이 크다. 본 실험에서 제공한 대본은 총 11 개 문장으 로 구성되어 있는 문단이었다. 문장은 평균 16 음절로 구성되어 있었고, 제일 긴 문장도 18 음절에 불과했다. 실제로 호흡 단위 내 평균 음절 수는 낭독 발화에서 17.2음절로 나타나서, 사실상 한 문장이 한 호흡 단위로 실현되었음을 알 수 있다. 따라서 본 연구 결과를 바탕으로 낭독 자료가 자유 발화보다 호흡 단위의 길이가 더 짧다고 일반화하기는 어렵다.

발화 과제에 따른 음절 수와 어절 수의 실현 양상은 조금 더 복잡하다. 휴지 단위 내 평균 발화 음절 수는 낭독 발화의 경우 12.5 음절, 자유 발화는 9.2 음절로, 휴지 단위의 길이가 더 길었 던 낭독 발화에서 더 많은 양의 음절을 발화하였다. 긴 발화에 서 더 많은 음절을 발화하는 것은 자연스럽다고 할 수 있다. 하 지만 휴지 단위 내 평균 발화 어절 수의 경우 낭독 발화와 자유 발화는 각각 4.19음절, 4.06음절로 큰 차이를 보이지 않았고 통 계적으로 유의미한 차이를 보이지 않았다. 낭독 발화가 자유 발 화보다 휴지 단위의 길이가 유의미하게 길었고, 휴지 단위 내 실현 음절 수가 유의미하게 많았음에도 불구하고, 휴지 단위 내 실현 어절 수에서는 유의미한 차이가 관찰되지 않았다. 이는 과 제 간 어절의 평균 길이 차이가 존재한 데서 그 원인을 찾을 수 있다.

한 어절당 발화된 음절 수를 계산해 보면, 낭독 발화는 어절 당 약 2.98음절(12.5음절/4.19어절), 자유 발화는 약 2.3 음절(9.2 음절/4.06어절)을 발화한 셈이다. 즉, 자유 발화는 더 짧은 음절 로 구성된 어절이 더 많이 실현된다. 이는 조사 생략이나 간투 사 실현이 잘 나타나는 자유 발화의 특징이 잘 반영된 결과라고 할 수 있다.

호흡 단위의 경우, 음절 수는 과제 간 차이를 보이지 않았고 어절 수는 과제의 차이가 있는 것으로 확인되었다. 호흡 단위의 길이가 낭독 발화보다 자유 발화에서 더 길게 나타났음에도 불 
구하고 각 과제에 따른 호흡 단위당 음절 수는 낭독 발화와 자 유 발화가 유의미한 차이를 보이지 않았다. 낭독 발화는 평균 $3,012 \mathrm{~ms}$ 의 한 호흡 단위 내에 평균 17.2음절을, 자유 발화 평균 $3,392 \mathrm{~ms}$ 의 한 호흡 단위 내에 평균 17.0 음절을 산출한다. 이러 한 실현 양상 또한 인지적 부담량에 따른 과제 간 차이를 잘 반 영해주는 것으로 보인다.

낭독 발화는 발화 계획이 필요하지 않기 때문에 화자에게 가 해지는 인지적 부담이 거의 없는 반면, 자유 발화에서는 화자의 발화 계획이 필요하다. 이 때문에 같은 길이의 호흡 단위로 발 화를 하더라도, 자유 발화를 수행할 때 화자는 한 호흡 단위 내 에 발화 계획을 위한 휴지의 실현이 지속적으로 요구된다. 따라 서 자유 발화에는 한 호흡 단위 내에 들숨을 동반하지 않은 휴 지 출연이 더 빈번하다. 실제로 인지적 부담량과 호흡 조정 간 상관관계를 조사한 Mitchell et al.(1996)에서도, 인지 언어적 요 구가 큰 과제일수록 호흡 단위당 음절 수와 발화 속도가 줄고, 묵음 휴지에 소비되는 시간이 늘어난다고 하였다. 이러한 차이 가 호흡 단위의 과제 차이를 야기한 것이다.

본 연구에서도 이러한 실현 양상을 확인할 수 있었다. 평균 호흡 단위의 길이와 음절 수를 바탕으로 말 속도를 계산해 보면, 자유 발화는 약 초당 5.71음절(17.2 음절 / 3.0초)을, 낭독 발화는 초당 5음절(17.0 음절 / 3.4초)을 발화한 셈이다. Mitchell et al.(1996)의 결과와 마찬가지로 자유 발화의 발화 속도가 낭독 발화보다 느린 것을 확인할 수 있다.

또, 호흡 단위와 휴지 단위의 과제 간 길이를 비교해 보면, 한 호흡 단위 내에 묵음 휴지의 실현 여부를 추론해 볼 수 있다. 자 유 발화의 호흡 단위는 평균 3.4 초, 휴지 단위는 평균 1.6 초로 나 타나는데, 이는 한 호흡 단위 내에 두 개 정도의 휴지 단위가 나 타날 수 있다는 것을 의미한다. 한 호흡 단위 내에 두 개의 휴지 단위가 나타난다는 것은 호흡 단위 내부에 묵음 휴지가 실현된 다는 뜻이다. 반면 낭독 발화의 호흡 단위의 길이는 평균 약 3 초, 휴지 단위의 길이는 평균 약 2.1초였던 점으로 미루어 보았을 때, 낭독 발화의 호흡 단위 내에는 두 개 이상의 휴지 단위가 나 타날 수도, 그렇지 않을 수도 있다. 즉, 낭독 발화의 호흡 단위 내에는 상대적으로 묵음 휴지가 잘 나타나지 않는다. 이상의 추 론을 통해, 낭독 발화의 호흡 단위 내에는 자유 발화의 호흡 단 위보다 더 빈번한 묵음 휴지가 실현될 것임을 짐작할 수 있다.

인지적으로 더 부담이 있는 자유 발화에서는 낭독 발화에서 보다 발화 속도가 느려지고 묵음 휴지의 출현이 빈번하다. 따라 서 자유 발화의 호흡 단위 길이가 낭독 발화보다 더 길게 나타 났더라도, 호흡 단위 안에 담고 있는 음절 수에서는 과제 간 차 이를 보이지 않은 것이다.

그런데 호흡 단위 내 음절 수가 두 과제에서 차이를 보이지 않았음에도 호흡 단위 내 어절 수는 과제의 차이를 보였다. 낭 독 발화는 호흡 단위 내 평균 5.82개의 어절이 실현되었고, 자유 발화는 평균 7.50개의 어절이 실현되었다. 이를 어절당 음절 수 로 계산해 보면, 낭독 발화는 약 어절당 약 2.96음절(17.2음절 15.82어절), 자유 발화는 2.26음절(17.0음절/7.50어절)로 나타난 다. 이 역시 짧은 어절이 많이 나타나는 자유 발화의 특징을 잘
드러내고 있음을 알 수 있다.

이상의 내용을 종합하여 과제에 따른 한국어 발화의 시간적 구성을 정리해 보면 다음과 같다. 낭독 발화는 일반적으로 약 3 초의 한 호흡 단위 내에 17 음절, 5.8 어절이 실현된다. 낭독 발화 의 휴지 단위는 약 2.1 초의 길이를 보이며, 그 안에 13 음절, 4.2 어절을 수행하는 것으로 관찰된다. 호흡 단위와 휴지 단위의 길 이 차이로 미루어 보았을 때, 호흡 단위 내에는 두 개 이상의 휴 지 단위가 나타날 가능성이 크지 않다. 즉, 호흡 단위 내 묵음 휴 지의 출현이 나타나지 않는 경우가 빈번하다. 그런데 낭독 발화 의 휴지 단위와 호흡 단위의 실현이 대본의 영향을 많이 받는 만큼, 낭독 대본이 대체로 짧은 문장들로만 구성되었던 본 연구 의 실험 결과만으로 낭독 발화의 시간 구성을 일반화하는 것은 어려움이 있을 수 있다.

자유 발화는 일반적으로 3.4 초의 호흡 단위 내에 17음절, 7.5 어절을 산출한다. 또 휴지 단위는 1.6초, 9음절, 4어절로 실현된 다. 위와 같은 시간 구성을 통해, 자유 발화의 호흡 단위 내에는 두 개 이상의 휴지 단위가 나타나는 경우가 빈번함을 추론할 수 있다. 위의 평균 수치를 바탕으로 자유 발화의 호흡 단위 구성 을 일반화 하면 그림 4와 같다.

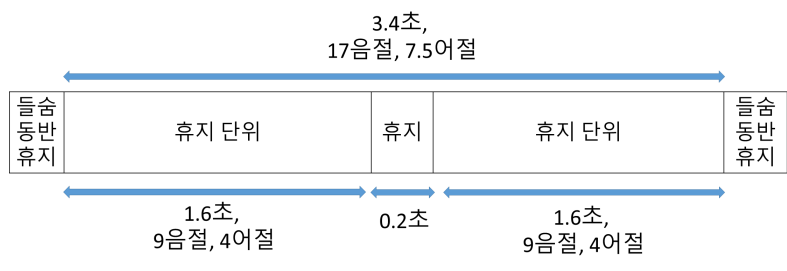

그림 4. 자유 발화의 호흡 단위 구성

Figure 4. Temporal organization of breath groups for spontaneous speech

한국어 화자는 대체로 약 3.4초를 한 호흡으로 발화할 수 있 다. 한 호흡 단위 내에서 화자는 약 1.6초를 발화하고 들숨 없이 0.2 초를 쉬며, 다시 1.6 초의 발화를 이어간다. 각 휴지 단위마다 약 9음절, 4어절을 발화하는데, 두 개의 휴지 단위가 한 호흡 단 위에서 발화되면 약 17 음절, 7.5 어절을 산출한다.

자유 발화의 이런 시간 구성은 한국어 자유 발화의 호흡 단위 와 휴지 단위를 연구한 $\operatorname{Shin}(2018)$ 의 연구 결과와 거의 동일한 결과이다. Shin(2018)에서는 한국어 화자가 평균 약 3 초의 호흡 단위의 길이를 보인다고 하였으며, 호흡 단위 내에서 1.5 초의 휴지 단위와 0.3 초의 들숨 비동반 휴지, 또 1.5 초의 휴지 단위가 연쇄된다고 하였다. 또 휴지 단위 내에는 9.4음절, 4어절이 발화 된다. 구어의 실현이 다양한 환경이나 여러 변수에 의해 상당한 정도의 변이성을 보인다는 점을 고려해 보았을 때, Shin(2018) 과 본 연구의 결과가 거의 유사하게 나타난다는 사실은 인간의 음성 언어가 일정 정도의 운율적 정규성을 갖고 실현된다는 사 실을 반영해주는 결과라고 할 수 있다.

이상을 통해 과제 차이가 휴지 단위와 호흡 단위에 영향을 주 는 주요한 변수임을 확인하였다. 특히 휴지 단위의 길이는 발화 계획과 같은 인지적 차이를 투명하게 반영해주는 변수였다. 길 
고 빈번한 휴지가 출현하는 자유 발화는 필연적으로 더 짧은 발 화 길이를 보이며, 본 연구에서도 이러한 양상을 확인하였다. 반면 호흡 단위의 길이는 자유 발화에서 더 길게 나타나, 과제 에 따른 인지적 차이를 단순히 반영하지는 않았다. 그러나 호흡 단위에 실현된 어절 수의 관계는 자유 발화와 낭독 발화의 과제 간 차이를 잘 보여주었다. 자유 발화는 낭독 발화보다 더 긴 길 이의 호흡 단위를 보임에도, 한 호흡 단위 내에 더 적은 음절 수 를 포함한다. 이는 발화 과제에 따른 인지적 차이를 반영한다. 또 휴지 단위와 호흡 단위 분석 모두에서, 자유 발화는 어절당 음절 수가 매우 적었는데, 이는 더 짧은 음절로 구성된 어절이 잘 나타나는 자유 발화의 특징을 잘 보여준다.

\section{2. 성별과 세대에 따른 실현}

성별은 휴지 단위와 호흡 단위 모두에 주요하게 영향을 미치 는 변수였다. 여성은 남성에 비해 휴지 단위의 길이가 길었고, 한 발화 단위 내의 음절 수와 어절 수도 많았다. 반면 호흡 단위 의 길이는 반대로 나타났는데, 남성이 여성보다 더 긴 길이의 호흡 단위를 보였고, 음절 수와 어절 수도 많았다.

남성의 휴지 단위 길이가 짧은 이유는, Yoo \& Shin(2019)에서 논의한 바와 같이 남성의 발화가 여성의 발화보다 더 길고 빈번 한 휴지 출현을 보이기 때문인 것으로 보인다. 더 길고 빈번한 휴지의 출현은 휴지 단위의 길이를 짧게 만드는 요인이 된다. 한편 호흡 단위의 길이는 조금 더 신체적인 차이를 반영하는 변 수라고 할 수 있다. Hixon et al.(1973)에 따르면 호흡 단위의 길 이는 폐활량의 수준을 반영하므로, 호흡 단위의 길이는 신체적 차이를 반영한다. 남성은 여성에 비해 폐활량이 더 커서 일회 호흡량 또한 더 크다(Lomauro \& Aliverti, 2018; Schoenberg \& Bouhyus, 1978). 그 결과 남성은 여성에 비해 한 숨으로 더 긴 길 이의 발화를 이어갈 수 있는 생리적인 조건을 갖추고 있다.

휴지의 유형별 실현 양상을 살핀 Yoo \& Shin(2019)에서도 실 제로 들숨 동반 휴지 길이가 남녀간 차이를 보인다는 것을 보고 하였는데, 남성이 여성보다 들숨 동반 휴지가 더 길게 나타난다 는 것이다. 들숨 동반 휴지의 길이가 반드시 들숨의 양을 의미하 는 것은 아니지만, 남성의 들숨 동반 휴지 구간의 길이가 더 길다 는 사실은 확인할 수 있었다. 또, 물리적 장치를 이용해 폐 용량 이나 호기와 흡기의 양을 조사한 많은 선행 연구들에서 이미 남 성의 일회 호흡량이 더 많은 것을 보고하고 있다. 이러한 신체적 차이가 호흡 단위의 성별 차이를 만들어낸 것으로 보인다.

한편 생리적 차이를 반영하므로 변수 간 차이를 보일 것이라 고 예상했던 세대 변수는 발화 길이와 호흡 단위 길이 모두에 영향을 미치지 않았다. 청년층 화자가 장년층 화자보다 휴지 단 위와 호흡 단위 모두 길게 실현한다는 경향성은 확인할 수 있었 으나, 이는 통계적으로 유의한 차이가 아니었다. 세대는 휴지 단위 내 음절 수와 어절 수, 그리고 호흡 단위 내 음절 수와 어절 수에는 영향을 주었다. 휴지 단위의 길이와 호흡 단위의 길이에 서는 세대 차이를 보이지 않았음에도, 음절 수와 어절 수는 장 년층 화자의 발화에서 유의하게 적었다. 이러한 결과는 두 세대 간 발화 속도의 차이를 반영하는 것이다. 한국인 청·장년층 화
자의 발화 속도를 연구한 Lee et al.(2017)에 따르면, 발화 속도는 세대에 따라 차이가 있었는데, 청년층이 장년층보다 말 속도와 조음 속도 모두 빠르게 나타난다. 따라서 비슷한 발화량을 산출 했다고 하더라도 청년층은 한 단위 안에 더 많은 양의 음절 수 와 어절 수를 발화할 수 있는 것이다.

한편 호흡 단위 내 음절 수와 호흡 단위 내 어절 수는 성별과 세대의 상호작용이 관찰되었다. 3.2절에서 확인했듯이, 청년층 남성의 호흡 단위 내 음절 수와 어절 수는 나머지 다른 집단에 비해 상당히 높은 값을 보였다. 호흡 단위 내 평균 음절 수의 경 우, 청년층 남성은 22.4음절이었는데 반해, 청년층 여성과 장년 층 남녀 화자는 각각 15.7 음절, 15.7 음절, 15.5 음절로 거의 차이 를 보이지 않았다. 호흡 단위 내 어절 수의 경우도, 청년층 남성 이 9.33음절로 가장 많았고 청년층 여성과 장년층 남녀 화자는 각각 6.48 어절, 6.77 어절, 6.64 어절이었다.

청년층 남성의 호흡 단위 내 음절 수와 어절 수가 다른 집단 에 비해 상당히 높은 값을 보임에 따라 성별 차이가 청년층에서 는 두드러지게 나타나지만 장년층에서는 그렇지 않은 결과를 보였으며 세대 차이 역시 남성은 두드러진 차이를 보이지만 여 성은 세대 차이가 관찰되지 않은 결과를 야기하였다.

이러한 차이 또한 과제, 세대에 따른 발화 속도 차이를 반영 하는 것이다. Lee et al.(2017)에 따르면 청년층 남성은 나머지 세 그룹보다 조음 속도가 유의미하게 빠르게 나타나는 집단이다. 따라서 청년층 남성은 한 호흡 단위 내에 가장 많은 음절 수와 어절 수를 산출할 수 있다.

세대 변수는 길이에 있어서는 차이를 드러내지 않는다. 들숨 을 쉬고, 조음을 하는 전체적인 발화의 시간 구성은 세대 간 차 이를 두드러지게 보이지 않는다. Yoo \& Shin(2019)에서도 휴지 의 길이가 성별 차이만 보일 뿐 세대 차이는 드러내지 않는다고 보고한 바가 있다. 발화의 시간적 구성은 성별의 차이를 두드러 지게 보여주는 운율적 요소임을 알 수 있다. 그러나 발화 단위 내에 산출되는 음절 수와 어절 수에는 차이가 있다. 이는 조음 속도의 차이이기도 하다. 조음 속도가 더 빠른 청년층이 장년층 보다 더 많은 음절 수를 산출한다. 특히 청년층 남성은 세 집단 중 가장 조음 속도가 빠른데, 따라서 휴지 단위와 호흡 단위 내 가장 많은 음절 수를 산출한다.

이상을 통해 발화를 구성하는 조음 구간과 휴지 구간의 시간 적 패턴은 주로 성별 차이를 두드러지게 반영한다는 것을 확인 할 수 있다. 그러나 조음 구간 내에 발화되는 음절 수와 어절 수 에는 차이가 있는데, 조음 속도가 빠른 청년층 남성이 다른 집 단에 비해 더 많은 음절 수와 어절 수를 산출한다. 조음 구간과 휴지 구간의 시간적 패턴이 세대 차이를 보이지 않았으며 음절 수와 어절 수에서만 차이를 보였다. 세대 차이를 드러내는 것은 휴지와 조음의 시간 구성이 아니라, 그 시간 안에 실제로 발화 된 언어적 내용이다. 즉, 전체적인 시간적인 패턴보다는 발화 속도가 세대 차이를 더 드러나게 한다. 이러한 결과를 확인하기 위해서는 실제로 청자들이 시간적 차이만으로는 세대 차이를 느끼지 못하는지에 대한 지각적인 연구가 뒷받침 되어야 할 것 으로 보인다. 


\section{5. 결론}

이 연구는 성인 화자의 휴지 단위와 호흡 단위의 실현을 관찰 하여, 과제, 세대, 성별이라는 변수들이 휴지 단위나 호흡 단위 실현에 어떠한 영향을 미치는지 살핀 연구이다. 이를 위하여 구 어 코퍼스인 '한국인 표준 음성 데이터 베이스'에서 청·장년층 남녀 화자 48 명을 선정하여 문단 낭독 발화와 자유 발화를 분석 하였다. 휴지 단위와 호흡 단위는 모두 지속 시간, 음절 수, 어절 수로 구분하여 실현 양상을 살피고 이에 대해 논의하였다.

발화 과제는 휴지 단위와 호흡 단위 실현에 모두 영향을 주는 변수였다. 휴지 단위의 길이는 자유 발화에서 더 짧았다. 이는 인지적으로 부담이 있는 자유 발화에서는 더 잦은 휴지 실현을 보이기 때문에 휴지 단위의 길이가 짧게 나타난다. 반면 호흡 단위의 길이는 자유 발화에서 더 길었는데, 이는 낭독 발화의 문장 길이가 다소 짧았던 데에 원인이 있는 것으로 보인다. 화 자들은 대체로 문장 경계에서 호흡을 위한 숨을 들이쉬는 경우 가 있기 때문에, 문장이 짧은 낭독 발화의 호흡 단위 길이가 짧 게 실현된 것이다. 한편 호흡 단위의 길이는 낭독 발화보다 자 유 발화에서 더 길었음에도, 한 호흡 단위 내에 음절 수는 자유 발화에서 더 적었다. 이러한 결과는 발화 과제에 따른 인지적 차이를 반영하는 것으로 보았다. 또, 자유 발화에서는 더 짧은 음절로 구성된 어절이 잘 나타났는데 이는 조사 생략이나 간투 사 삽입과 같은 자유 발화의 특성을 잘 보여주는 결과라고 할 수 있다.

성별은 휴지 단위와 호흡 단위에 주요하게 영향을 미치는 변 수였다. 여성은 남성에 비해 휴지 단위의 길이가 길었고, 한 발 화 단위 내의 음절 수와 어절 수도 많았다. 이는 남성의 발화가 여성의 발화보다 더 길고 빈번한 휴지 출현을 보이기 때문이다. 더 길고 빈번한 휴지의 출현은 더 짧은 발화 길이를 초래한다. 반면 호흡 단위의 길이는 이와 반대로 나타났는데, 남성이 여성 보다 더 긴 길이의 호흡 단위를 보였으며, 호흡 단위 내 음절 수 와 어절 수도 남성의 발화에서 더 많이 실현되었다. 이러한 결 과는 남성과 여성의 폐활량 차이에서 비롯한 것으로 보인다. 폐 활량이 큰 남성은 여성에 비해 일회 호흡량이 크기 때문에, 한 숨으로 더 긴 길이의 발화를 이어나갈 수 있다.

한편 세대는 발화 길이와 호흡 단위 길이 모두에 영향을 미치 지 않았다. 청년층 화자가 장년층 화자보다 휴지 단위의 길이와 호흡 단위 모두 길게 실현한다는 경향성은 확인할 수 있었으나, 통계적으로 유의한 정도의 차이는 아니었다. 그런데 세대 변수 는 음절 수와 어절 수에는 영향을 주었다. 휴지 단위의 길이와 호흡 단위의 길이는 세대 차이를 보이지 않았음에도, 음절 수와 어절 수는 장년층 화자의 발화에서 유의하게 적었다. 이는 두 세대의 발화 속도 차이를 반영하는 결과라고 할 수 있다.

세대와 성별의 상호작용이 관찰되는 종속 변수들도 존재하 였다. 호흡 단위 내 음절 수와 호흡 단위 내 어절 수는 성별화 세 대의 상호작용을 보였는데, 둘 모두 청년층 남성의 값이 다른 집단에 비해 상당히 높은 값을 보였다. 이러한 차이는 호흡 단 위의 길이에서도 확인할 수 있었는데, 청년층 남성의 호흡 길이
가 다른 집단에 비해 길게 나타났다. 따라서 성별 차이는 청년 층에서만 두드러지게 나타나고 장년층에서는 그렇지 않은 상 호작용을 보였으며, 세대 차이 역시 남성은 두드러진 차이를 보 이지만 여성은 세대 간 차이가 관찰되지 않았다.

휴지 단위와 호흡 단위는 인지적, 생리적, 사회 언어적 요소 등에 따라 다른 실현 양상을 보일 수 있음에도, 지금까지는 이 를 면밀하게 살펴본 연구는 거의 없었다. 이 연구는 휴지 단위 와 호흡 단위의 실현에 영향을 미치는 요인에 대해 인지적, 생 리적, 사회 언어학적 해석을 시도하였다는 점에서 의의를 갖는 다. 또한 이 연구는 단지 발화 길이나 호흡 단위의 길이 분석에 서 그치는 것이 아니라, 음절 수와 어절 수에 대한 분석도 병행 하여, 한국어 발화 단위의 시간적 구성에 대한 기초 자료를 제 공하였다. 아울러, 장애 여부를 판단할 수 있는 규준이 될 수 있 는 비장애 성인 화자에 대한 기초 자료를 제공한다는 점에서도 의의를 갖는다고 할 수 있다.

단, 발화 길이나 호흡 단위와 같은 발화의 시간적 구성 요소 는 본 연구에서 중심적으로 살펴보았던 과제, 성별, 세대와 같 은 변수 외에도 문법적인 구조나 흡연 여부 등과 같은 다양한 요인에 의해 영향을 받을 수 있다. 따라서 앞으로의 연구에서는 이러한 점들을 고려한 더욱 다각적인 연구가 이루어질 필요가 있다. 더불어, 성별이나 세대 차이를 보이는 이유가 단순히 생 리학적 차이에서 기인한 것인지, 혹은 사회 문화적인 차이에서 기인한 것인지를 구분해 내기 위해서는 더 깊은 고려가 필요하 다. 이러한 문제를 해결하기 위해서는 사회언어학적 변수에 따 른 발화 실현과 관련한 더 많은 연구들이 축적되어야만 한다. 이 연구 또한 향후 여러 연구를 위한 밑받침이 될 수 있을 것으 로 기대한다.

\section{References}

Bailly, G., \& Gouvernayre, C. (2012, September). Pauses and respiratory markers of the structure of book reading. Proceedings of the 13th Annual Conference of the International Speech Communication Association 2012 (pp. 2218-2221). Portland, OR.

Cappella, J. N. (1985). The management of conversations. In M. L. Knapp \& G. R. Miller (Eds.), The handbook of interpersonal communication (pp. 393-438). Beverly Hills, CA: Sage.

Chon, H.C., \& Lee, S. B. (2019). Characteristics of speech rates and utterance lengths in fluent and disfluent utterance of aduls who stutter. Audiology and Speech Research, 15(3), 214-222.

Clopper, C., \& Smiljanic, R. (2015). Regional variation in temporal organization in American English. Journal of Phonetics, 49, 1-15.

Ferreira F. (1991). Effects of length and syntactic complexity on initiation times for prepared utterances. Journal of Memory and Language, 30(2), 210-233.

Foulkes, P., \& Docherty, G. (2006). The social life of phonetics and phonology. Journal of Phonetics, 34(4), 409-438.

Henderson, A., Goldman-Eisler, F., \& Skarbek, A. (1965). Temporal 
patterns of cognitive activity and breath control in speech. Language and Speech, 8(4), 236-242.

Henderson, A., Goldman-Eisler, F., \& Skarbek, A. (1966). Sequential temporal patterns in spontaneous speech. Language and Speech, 9(4), 207-216.

Hixon, T. J., Goldman, M. D., \& Mead, J. (1973). Kinematics of the chest wall during speech production: Volume displacement of the rib cage, abdomen, and lung. Journal of Speech and Hearing Research, 16(1), 78-115.

Jung, Y. H., \& Yoon, M. S. (2013). Mean length of utterance for typically developing children of 2 to 4 years. The Korean Journal of Early Childhood Special Education, 13(3), 55-73.

Kendall, T. S. (2009). Speech rate, pause and linguistic variation: An examination through the sociolinguistic archive and analysis project (Doctoral dissertation). Duke University, Durham, NC.

Kendall, T. S. (2013). Speech rate, pause and sociolinguistic variation: Studies in corpus sociophonetics. London, UK: Palgrave Macmillan.

Kim, J. (2017). The influence of utterance length on speech rate in spontaneous speech. Phonetics and Speech Sciences, 9(1), 9-17.

Lee, I. A., Lee, H. E., \& Hwang, Y. Jin. (2012). The study of breath competence depending on utterance condition by healthy speakers: A preliminary study. Phonetics and Speech Sciences, 4(2), 115-120.

Lee, N., Shin, J., Yoo, D., \& Kim, K.W. (2017). Speech rate in Korean across region, gender and generation. Phonetics and Speech Sciences, 9(1), 27-39.

Lee, S. J., \& Hwang, M. N. (2001). The trade-off effects between MLU and fluency in normal preschool-age children. Speech Sciences, 8(4), 157-168.

Libermann, P. (1967). Intonation, perception, and language. Cambridge, MA: MIT Press.

LoMauro, A., \& Aliverti, A. (2018). Sex differences in respiratory function. Breathe, 14(2), 131-140.

Mitchell, H. L., Hoit, J. D., \& Watson, P. J. (1996). Cognitive linguistic demands and speech breathing. Journal of Speech, Language, and Hearing Research, 39(1), 93-104.

Rochet-Capellan, A., \& Fuchs, S. (2013, August). The interplay of linguistic structure and breathing in german spontaneous speech. Proceedings of the 14th Annual Conference of the International Speech Communication Association (p. 1228). Lyon, France.

Schoenberg, J. B., Beck, G. J., \& Bouhuys, A. (1978). Growth and decay of pulmonary function in healthy blacks and whites. Respiration Physiology, 33(3), 367-393.

Shin, J. (2013). How to maximize efficiency of communication: A prosodic analysis. Journal of the Society of Korean Language and Literature, 69, 113-133.

Shin, J. (2018). Breath and memory in speech based on quantitative analysis of breath groups and pause units in Korean. Korean Linguistics, 79, 91-116.

Shin, J., \& Kim, K.W. (2017). Developing a Korean standard speech DB (II). Phonetics and Speech Sciences, 9(2), 9-22.

Sperry, E. E., \& Klich, R. J. (1992). Speech breathing in senescent and younger women during oral reading. Journal of Speech, Language, and Hearing Research, 35(6), 1246-1255.

Strand, E. A., Johnson, K., \& D’Imperio, M. (1999). Auditory-visual integration of talker gender in vowel perception. Journal of Phonetics, 27(4), 359-384.

Wang, Y. T., Green, J. R., Nip, I. S. B., Kent, R. D., \& Kent, J. F. (2010). Breath group analysis for reading and spontaneous speech in healthy adults. Folia Phoniatrica et Logopaedica, 62(6), 297-302.

Watson, D., \& Gibson, E. (2004). The relationship between intonational phrasing and syntactic structure in language production. Language and Cognitive Processes, 19(6), 713-755.

Wennerstrom, A., \& Siegel, A. F. (2003). Keeping the floor in multiparty conversations: Intonation, syntax, and pause. Discourse Processes, 36(2), 77-107.

Winkworth, A. L., Davis, P. J., Ellis, E., \& Adams, R. D. (1994). Variability and consistency in speech breathing during reading: Lung volumes, speech intensity, and linguistic factors. Journal of Speech, Language, and Hearing Research, 37(3), 535-56.

Winkworth, A. L., Davis, P. J., Ellis, E., \& Adams, R. D. (1995). Breathing patterns during spontaneous speech. Journal of Speech, Language, and Hearing Research, 38(1), 124-144.

Yoo, D., \& Shin, J. (2019). A realization of pauses in utterance across speech style, gender, and generation. Phonetics and Speech Sciences, 11(2), 33-44.

\section{- 유도영 (Doyoung Yoo)}

고려대학교 국어국문학과 박사과정

서울시 성북구 안암로 145

Tel: 02-3290-2505

Email: doong723@korea.ac.kr

관심분야: 음성학, 음운론

\section{- 신지영 (Jiyoung Shin) 교신저자} 고려대학교 국어국문학과 교수 서울시 성북구 안암로 145

Tel: 02-3290-1972

Email: shinjy@korea.ac.kr 관심분야: 음성학, 음운론 
부록 1.

낭독 대본

남일이네 야옹이는 멍멍이를 미워합니다. 야옹이는 멍멍이의 마음을 모릅니다. 그래서 멍멍이랑 놀아주지 않습니다. 은행 나무 위에는 야옹이만 올라옵니다. 무모한 멍멍이는 나무 위 로 날아오릅니다. 그렇지만 너무 높아서 오르기가 어렵습니 다. 야옹이는 매일매일 나무 위에 머무릅니다. 위에서 얄미운 울음만 웁니다. 나무 아래 누워있는 멍멍이는 무료합니다. 야 옹이는 야밤에만 아래로 내려옵니다. 우울한 멍멍이는 애먼 나를 원망합니다. 


\title{
휴지 단위와 호흡 단위의 실현 양상 연구*
}

\author{
유도영 - 신지영 \\ 고려대학교 국어국문학과
}

\begin{abstract}
국문초록
이 연구의 목적은 성인 화자의 휴지 단위와 호흡 단위의 실현 양상을 관찰하여, 이것이 인지적 차이나 사회 언어적 변수 간 차이를 어떻게 반영하고 있는지 고찰하는 것이다. 이러한 차이를 고찰하기 위해 과제, 세대, 성별에 따른 발화 길이와 호흡 단위의 실현을 살펴보았다. 이를 위해 청-장년층 남녀 화자 48 명의 문단 낭독 발화와 자유 발화를 분석하였다. 과제와 성별 변수는 휴지 단위와 호흡 단위 실현에 모두 영향을 주었다. 발화 길이는 낭독 발화에서, 여성의 발화에서 더 길었고, 호흡 단위의 길이는 자유 발화와 남성의 발화에서 더 길게 나타났다. 한편 세대 변수는 발화 길이 실현에는 영향을 주지 못했지만, 음절 수와 어절 수 실현에는 영향을 주었다. 발화 과제에 따른 차이는 인지적 부담량을 반영한다. 발화 계획이 빈번하게 이뤄져야 하는 자유 발화는 상대적으로 더 짧은 발화 길이를 보 인다. 호흡 단위의 길이가 낭독 발화에서 더 짧았던 이유는 낭독 발화의 문장 길이에 영향을 받은 것이다. 성별에 따른 차이는 남성과 여성의 발화 내 휴지 패턴 차이에서 기인하였다. 호흡 단위의 경우 남성이 여성보다 더 긴 길이 를 보였는데, 이는 남성과 여성의 폐활량 차이에서 비롯한 것으로 보인다. 세대는 음절 수와 어절 수 실현에만 영향 을 주었는데, 이는 세대 간 발화속도 차이에서 기인한 결과로 해석할 수 있다.
\end{abstract}

핵심어: 휴지, 휴지 단위, 호흡, 호흡 단위, 발화 길이, 운율, 시간 패턴

\section{참고문헌}

김정선 (2017). 자연발화 음성 코퍼스에서 발화 속도에 대한 발화 길이의 영향. 말소리와 음성과학, 9(1), 9-17.

신지영 (2013). 소통과 공감을 위한 전달력 높은 말하기의 언어학 적 조건: 운율적 측면을 중심으로. 어문논집, 69, 113-133.

신지영 (2018). 언어 수행에서의 호흡과 기억: 호흡 단위와 휴지 단위의 양적 분석 결과를 바탕으로. 한국어학, 79, 91-116.

신지영, 김경화 (2017). 한국인 표준 음성 DB 구축(II). 말소리와 음성과학, 9(2), 9-22.

유도영, 신지영 (2019). 과제, 성별, 세대에 따른 휴지의 실현 양상 연구. 말소리와 음성과학, 11(2), 33-44.

이나라, 신지영, 유도영, 김경화(2017). 한국어 발화 속도의 지역, 성별, 세대에 따른 특징 연구. 말소리와 음성과학, 9(1), 27-39. 이수진, 황민아 (2001). 발화길이와 유창성 간의 교환효과: 언어 발달시기에 있는 36 48개월의 정상아동을 대상으로. 음성과 학, 8(4), 157-168.

이인애, 이혜은, 황영진 (2012). 발화조건에 따른 정상 성인의 호흡 능력 차이 비교: 예비연구. 말소리와 음성과학, 4(2), 115-120.
전희경, 이수복 (2019). 말더듬 성인의 유창한 발화와 비유창한 발화의 말속도 및 발화 길이 특성. 청능재활, 15(3), 214-222.

정윤희, 윤미선 (2013). 2, 3, 4세 일반 아동의 평균발화길이. 유아 특수교육연구, 13(3), 55-73.

\footnotetext{
* 이 논문 또는 저서는 2019년 대한민국 교육부와 한국연구재단의 지원을 받아 수행된 연구임 (NRF-2019S1A5A2A03044146)
} 